\title{
Solitary pancreatic metastasis from breast cancer: case report and review of literature
}

\author{
Márcio Apodaca-Rueda', Fábio Henrique Mendonça Chaim", Milena da Silva Garcia", Helena Paes de Almeida de Saito'"', \\ Martinho Antonio Gestic ${ }^{\mathrm{IV}}$, Murillo Pimentel Utriniv ${ }^{\mathrm{iv}}$, Francisco Callejas-Netov, Elinton Adami Chaim', Everton Cazzo ${ }^{\mathrm{VII}}$
}

Department of Surgery, Faculdade de Ciências Médicas da Universidade Estadual de Campinas (FCM-UNICAMP), Campinas (SP), Brazil

\author{
'Medical Student, Faculdade de Medicina da \\ Pontíficia Universidade Católica de Campinas \\ (PUC-Campinas), Campinas (SP), Brazil. \\ "MD. Resident Physician, Department of Surgery, \\ Faculdade de Ciências Médicas da Universidade \\ Estadual de Campinas (FCM-UNICAMP), \\ Campinas (SP), Brazil. \\ "'MD. Assistant Lecturer, Oncology Unit - \\ Department of Internal Medicine, Faculdade de \\ Ciências Médicas da Universidade Estadual de \\ Campinas (FCM-UNICAMP), Campinas (SP), Brazil. \\ "MD, MSc. Assistant Lecturer, Department of \\ Surgery, Faculdade de Ciências Médicas da \\ Universidade Estadual de Campinas \\ (FCM-UNICAMP), Campinas (SP), Brazil. \\ 'MD, MSc. Assistant Professor, Department of \\ Surgery, Faculdade de Ciências Médicas da \\ Universidade Estadual de Campinas \\ (FCM-UNICAMP), Campinas (SP), Brazil. \\ "MD, MSC, PhD. Full Professor, Department of \\ Surgery, Faculdade de Ciências Médicas da \\ Universidade Estadual de Campinas \\ (FCM-UNICAMP), Campinas (SP), Brazil. \\ VIIMD, PhD. Adjunct Professor, Department of \\ Surgery, Faculdade de Ciências Médicas da \\ Universidade Estadual de Campinas \\ (FCM-UNICAMP), Campinas (SP), Brazil.
}

\section{KEY WORDS:}

Breast neoplasms.

Pancreas.

Neoplasm metastasis.

Pancreatic neoplasms.

Carcinoma, ductal, breast.

\begin{abstract}
CONTEXT: Pancreatic metastases from primary malignant tumors at other sites are rare, constituting about $2 \%$ of the neoplasms that affect the pancreas. Pancreatic metastasis from breast cancer is extremely rare and difficult to diagnose, because its clinical and radiological presentation is similar to that of a primary pancreatic tumor.

CASE REPORT: A 64-year-old female developed a lesion in the pancreatic tail 24 months after neoadjuvant therapy, surgery and adjuvant radiation therapy for right-side breast cancer (ductal carcinoma). She underwent distal pancreatectomy with splenectomy and left adrenalectomy, and presented an uneventful outcome. The immunohistochemical analysis on the surgical specimen suggested that the lesion originated from the breast.

CONCLUSION: In cases of pancreatic lesions detected in patients with a previous history of breast neoplasm, the possibility of pancreatic metastasis should be carefully considered.
\end{abstract}

\section{INTRODUCTION}

Pancreatic metastases from primary malignant tumors at other sites are rare, constituting about $2 \%$ of the neoplasms that affect the pancreas. ${ }^{1}$ In most cases, the involvement occurs through hematological and lymphatic dissemination, as in cases of kidney and lung carcinomas. It can also occur through contiguous invasion of neighboring organs such as the liver, stomach and spleen. Pancreatic metastasis from breast cancer is extremely rare and difficult to diagnose, because its clinical and radiological presentation is similar to that of a primary pancreatic tumor. ${ }^{2-5}$ The objective of the present study was to report on a case of pancreatic metastasis of breast cancer, along with the treatment that was proposed.

\section{CASE REPORT}

A 64-year-old female underwent neoadjuvant chemotherapy consisting of doxorubicin, cyclophosphamide and paclitaxel, with subsequent quadrantectomy and axillary lymph node dissection due to a right-side breast neoplasm. Histopathological examination revealed a ductal carcinoma classified as T2N2M0, consisting of a 4-cm tumor with spreading to six axillary lymph nodes but without distant spreading to bones, liver, brain or lungs). It was triple-negative, for estrogen, progesterone and human epidermal growth factor receptor 2 (HER2) receptors. Radiation therapy was subsequently implemented. The patient was then followed up with serial investigations (mammogram, bone scintigraphy scan and computed tomography scans of the cranium, thorax and abdomen) for locoregional and distant relapses every six months.

Twenty-four months after receiving the diagnosis, she evolved with a complaint of left-flank pain, inappetence and loss of seven kilograms in four months. She presented dyspeptic symptoms characterized by early satiety and pain in the upper abdomen after feeding. On physical examination, the abdomen was painful to deep palpation. There was no evidence of relevant laboratory abnormalities.

Abdominal computed tomography demonstrated a hypervascularized solid lesion of $6.6 \mathrm{~cm}$ x 6.0 $\mathrm{cm} \times 7.0 \mathrm{~cm}$ in the tail of the pancreas. It had an irregular outline and partially defined borders, presented a central area of necrosis and was in contact with the anterior margin of the spleen and greater gastric curvature. It was not possible to determine any cleavage plane. A small amount of free liquid was present (Figure 1). Cancer antigen (CA)-19.9, carcinoembryonic antigen (CEA) and CA-125 levels 
were within the normal ranges. No other sites with suspected lesions were detected through positron-emission computed tomography.

Because the hypothesis of pancreatic neoplasia needed to be clarified and no endoscopic ultrasound-guided biopsy was available, prompt surgery was warranted given that there was no evidence of other sites of active disease. The patient underwent distal pancreatectomy with splenectomy and left adrenalectomy (Figure 2), with uneventful postoperative outcomes. She had good evolution in the postoperative period, with complete remission of symptoms.

The histopathological diagnosis consisted of metastasis from breast carcinoma. The results from the immunohistochemical analysis were positive for the cytokeratin-7 (CK7) marker and negative for the mucin 5AC (MUC-5AC), CEA, CA-19.9, estrogen receptor (ER), progesterone receptor (PR) and Breast-2 (BRST2) markers. Although negativity for ER, PR and BRST-2 does not favor a breast origin, these markers do not preclude this origin. On the other hand, negativity for the MUC-5AC, CEA and CA-19.9

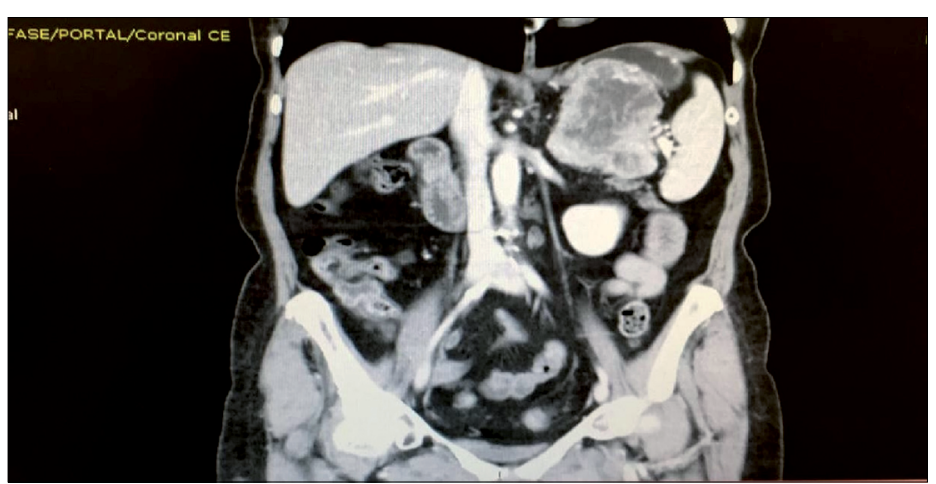

Figure 1. Computed tomography showing a lesion in the tail of the pancreas.

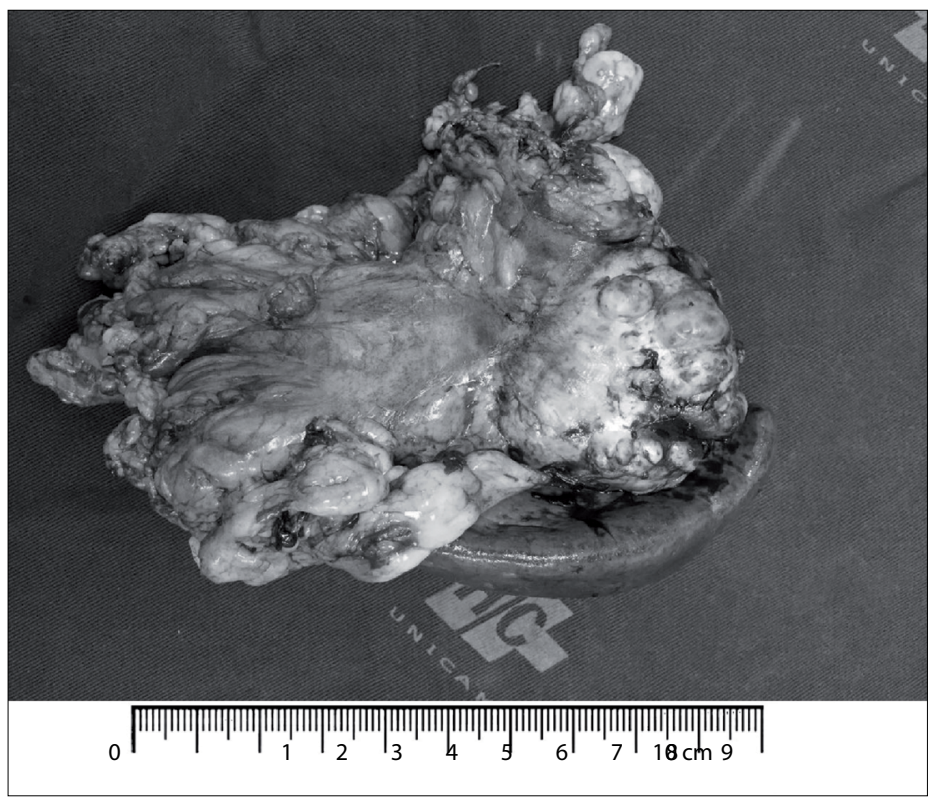

Figure 2. Surgical specimen (distal pancreatectomy with splenectomy and left adrenalectomy). markers does not favor a pancreatobiliary origin and favors the breast as the primary site. A chemotherapy regimen consisting of paclitaxel was administered for 12 weeks following the patient's recovery from the operation, and currently she is being followed up with serial screenings for locoregional and distant spreading of disease every six months. As of 18 months after the diagnosis was made, there is no evidence of active disease.

\section{DISCUSSION}

Breast cancer causes metastases especially to bones, liver and lungs. Pancreatic involvement in solitary metastases from a primary breast neoplasm is rare, occurring in less than $3 \%$ of the cases. A review of the literature was conducted through an online search for the Medical Subject Headings (MeSH) terms "breast neoplasms", "pancreas" and "neoplasm metastasis" in MEDLINE (via PubMed) and LILACS (via BVS) (Table 1). We included original studies that reported single cases or case series of this disease or correlated conditions. All the papers were checked according to their titles and abstracts (screening). Full papers were obtained from journals available on the website of the Commission for Improvement of Higher Education Personnel (Comissão de Aperfeiçoamento de Pessoal de Nível Superior, CAPES) (Ministry of Education, Brazil). Unavailable articles were requested from their authors. Articles presenting potentially relevant studies were read and analyzed to assess the inclusion criteria. We excluded articles that consisted of in vitro or animal studies, articles in which the participants' characteristics did not match those mentioned above, poster session abstracts, review articles and other types of publications. Other papers were used for contextualization and discussion.

After extensive online research, we identified 23 studies, 17 case reports and 6 case series, totaling 28 reported cases of pancreatic metastases from breast cancer. Table $2^{2,3,6-8,10-27}$ summarizes the main articles found and their reported outcomes. Figure 3 presents a flow diagram of the articles selected. In the majority of the cases described, spreading to the head of the pancreas was more

Table 1. Database search results for pancreatic metastasis arising from primary breast cancer

$\begin{array}{lcc}\begin{array}{l}\text { Electronic } \\ \text { databases }\end{array} & \text { Search strategies } & \text { Results } \\ \text { MEDLINE } & \text { (Breast neoplasms) AND } & 17 \text { case reports } \\ \text { (PubMed) } & \text { (Pancreas) AND (Neoplasm } & 6 \text { case series } \\ & \text { Metastasis) } & \\ & ((\text { Breast neoplasms) OR } \\ & \text { (Neoplasias da mama) OR } \\ & \text { (Neoplasias de la mama)) } \\ & \text { AND ((Pancreas) OR } & \\ \text { LILACS (BVS) } & \text { (Pâncreas) OR (Páncreas)) } & 1 \text { case report } \\ & \text { AND ((Neoplasm } & \\ & \text { Metastasis) OR (Metástase } \\ & \text { Neoplásica) OR (Metástasis } \\ & \text { de la Neoplasia))) }\end{array}$


Table 2. Reported cases of pancreatic metastases arising from primary breast cancer

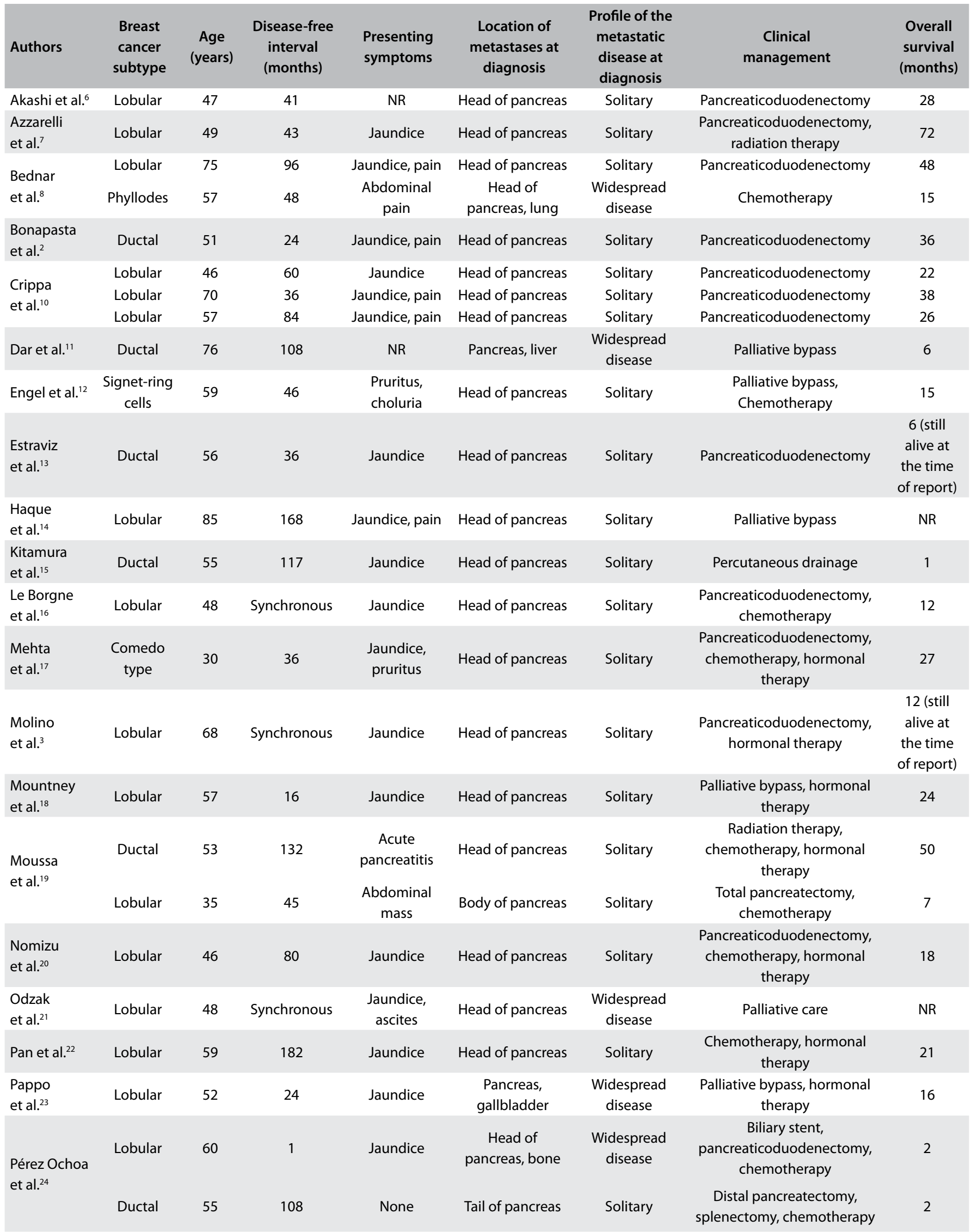


Table 2. Continuation

\begin{tabular}{|c|c|c|c|c|c|c|c|c|}
\hline Authors & $\begin{array}{l}\text { Breast } \\
\text { cancer } \\
\text { subtype }\end{array}$ & $\begin{array}{c}\text { Age } \\
\text { (years) }\end{array}$ & $\begin{array}{l}\text { Disease-free } \\
\text { interval } \\
\text { (months) }\end{array}$ & $\begin{array}{l}\text { Presenting } \\
\text { symptoms }\end{array}$ & $\begin{array}{l}\text { Location of } \\
\text { metastases at } \\
\text { diagnosis }\end{array}$ & $\begin{array}{l}\text { Profile of the } \\
\text { metastatic } \\
\text { disease at } \\
\text { diagnosis }\end{array}$ & $\begin{array}{c}\text { Clinical } \\
\text { management }\end{array}$ & $\begin{array}{c}\text { Overall } \\
\text { survival } \\
\text { (months) }\end{array}$ \\
\hline $\begin{array}{l}\text { Tohnosu } \\
\text { et al. }{ }^{26}\end{array}$ & $\begin{array}{l}\text { Scirrhous } \\
\text { type }\end{array}$ & 54 & 52 & None & Tail of pancreas & Solitary & $\begin{array}{c}\text { Distal pancreatectomy, } \\
\text { chemotherapy, hormonal } \\
\text { therapy }\end{array}$ & 5 \\
\hline $\begin{array}{l}\text { Z'graggen } \\
\text { et al. }{ }^{27}\end{array}$ & Lobular & NR & 96 & Jaundice & Head of pancreas & Solitary & $\begin{array}{l}\text { Biliary and gastric bypass, } \\
\text { chemotherapy }\end{array}$ & 54 \\
\hline $\begin{array}{l}\text { Current } \\
\text { study }\end{array}$ & Ductal & 64 & 24 & Pain & Tail of pancreas & Solitary & $\begin{array}{l}\text { Distal pancreatectomy, } \\
\text { chemotherapy }\end{array}$ & $\begin{array}{l}18 \text { (still } \\
\text { alive at } \\
\text { the time } \\
\text { of report) }\end{array}$ \\
\hline
\end{tabular}

$N R=$ not reported

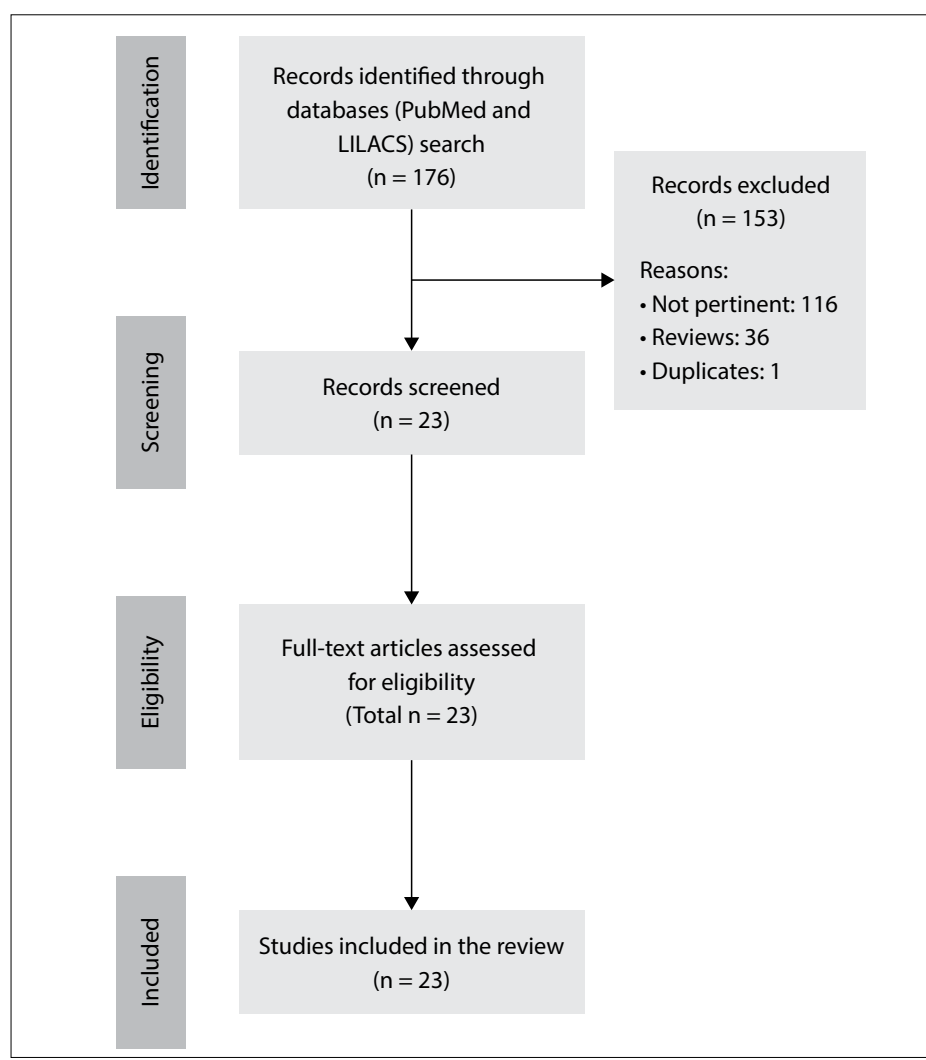

Figure 3. Flow diagram of the review of the literature.

common than to the tail, and the most common histological type was lobular carcinoma; the predominant metastatic pattern was solitary. The average interval between the diagnoses of primary breast neoplasm and pancreatic metastasis was 43.3 months. ${ }^{2}$ In our case, the patient presented metastasis to the region of the tail of the pancreas, with a histopathological diagnosis of ductal carcinoma, and the asymptomatic interval was 24 months.

The clinical signs of this condition are unspecific, with abdominal pain and obstructive jaundice as the main findings. ${ }^{4}$ The absence of characteristic clinical signs and symptoms leads to investigation by means of imaging tests. Ultrasonography, computed tomography and magnetic resonance imaging are frequently used for making this diagnosis; however, the radiological features of primary pancreatic tumors and pancreatic metastases are difficult to differentiate. Use of serum markers such as CA-15.3 may help in making the diagnosis, although in some cases its serum elevation is not relevant. . $^{25-9,28}$ The most accurate diagnostic method is pancreatic biopsy. Some studies have suggested that fine-needle biopsies guided by endoscopic ultrasound or percutaneously should be used. ${ }^{3}$ The unavailability both of tests for this marker and of endoscopic ultrasound at our service precluded their use in the present case; however, this should not prevent the oncology and surgery teams from recommending operative treatment in cases without widespread disease.

The prognosis for patients with pancreatic metastatic disease is usually better than for patients with primary pancreatic tumors. ${ }^{2}$ Masetti et al. analyzed the prognostic factors relating to metastatic tumors in the pancreas and found two and five-year survival rates of $57.1 \%$ and $34.3 \%$ in cases of pancreatic metastasis due to breast cancer, respectively. ${ }^{28}$ Surgical resection in cases with disease limited to the pancreas is considered to be the main form of treatment, despite its morbidity. ${ }^{3}$

\section{CONCLUSION}

Based on this study and the evidence available to date, it may be concluded that in cases of pancreatic lesions detected in patients with previous histories of breast neoplasms, the possibility of pancreatic metastasis should be carefully considered.

\section{REFERENCES}

1. Reddy S, Wolfgang CL. The role of surgery in the management of isolated metastases to the pancreas. Lancet Oncol. 2009;10(3):287-93.

2. Bonapasta SA, Gregori M, Lanza R, et al. Metastasis to the Pancreas from Breast Cancer: Difficulties in Diagnosis and Controversies in Treatment. Breast Care (Basel). 2010;5(3):170-3. 
3. Molino C, Mocerino C, Braucci A, et al. Pancreatic solitary and synchronous metastasis from breast cancer: a case report and systematic review of controversies in diagnosis and treatment. World J Surg Oncol. 2014;12:2.

4. Motos Micó JJ, Velasco Albendea FJ, Barrera Casallas C, Quijano Moreno SL, Rosado Cobián R. Metástasis ampular por carcinoma lobulillar de mama [Ampular metastasis of a breast lobulillar carcinoma.]. Cirugía Española. 2016;94(2):e45-e47. Available from: http://www.elsevier. es/es-revista-cirugia-espanola-36-articulo-metastasis-ampular-porcarcinoma-lobulillar-S0009739X14003388. Accessed in 2017 (Aug 14).

5. Sperti C, Moletta L, Patanè G. Metastatic tumors to the pancreas: The role of surgery. World J Gastrointest Oncol. 2014;6(10):381-92.

6. AkashiY, Saiura A, KishiY, et al. Outcome after surgical resection of isolated metastases to the pancreas. Hepatogastroenterology. 2010;57(104):1549-52.

7. Azzarelli A, Clemente C, Quagliuolo V, Battici F. A case of pancreatoduodenectomy as resolutive treatment for a solitary metastasis of breast cancer. Tumori. 1982;68(4):331-5.

8. Bednar F, Scheiman JM, McKenna BJ, Simeone DM. Breast cancer metastases to the pancreas. J Gastrointest Surg. 2013;17(10):1826-31.

9. Bonapasta SA, Gregori M, Lanza R, et al. Metastasis to the Pancreas from Breast Cancer: Difficulties in Diagnosis and Controversies in Treatment. Breast Care (Basel). 2010;5(3):170-3.

10. Crippa S, Angelini C, Mussi C, et al. Surgical treatment of metastatic tumors to the pancreas: a single center experience and review of the literature. World J Surg. 2006;30(8):1536-42.

11. Dar FS, Mukherjee S, Bhattacharya S. Surgery for secondary tumors of the pancreas. HPB (Oxford). 2008;10(6):498-500.

12. Engel JJ, Trujillo Y, Spellberg M. Metastatic carcinoma of the breast: a cause of obstructive jaundice. Gastroenterology. 1980;78(1):132-5.

13. Estraviz B, Pocino R, Landaluce A, Mendarte U, Sarabia S. Metástases pancreática solitaria de carcinoma de mama [Solitary pancreatic metastasis from breast cancer]. Cirugía Española. 2002;72(2):111-2. Available from: http://www.elsevier.es/es-revista-cirugia-espanola36-articulo-metastasis-pancreatica-solitaria-carcinoma-mamaS0009739X02720204. Accessed in 2017 (Aug 14).

14. Haque S, Gopaldas RR, Plymyer MR, Glantz Al. Pancreatic mass of unusual etiology: case report of metastatic disease after a prolonged lag phase. Am Surg. 2005;71(12):1082-5.

15. Kitamura N, Murata $\mathrm{S}, \mathrm{Abe} \mathrm{H}$, et al. Obstructive jaundice in a metastatic tumor of the pancreas from breast cancer: a case report. Jpn J Clin Oncol. 2003;33(2):93-7.

16. Le Borgne J, Partensky C, Glemain P, Dupas B, de Kerviller B. Pancreaticoduodenectomy for metastatic ampullary and pancreatic tumors. Hepatogastroenterology. 2000;47(32):540-4.

17. Mehta SA, Jagannath P, Krishnamurthy SC, De Souza LG. Isolated pancreatic metastasis from locally controlled breast cancer: a case report. Indian J Cancer. 1991;28(1):48-50.
18. Mountney J, Maury AC, Jackson AM, Coleman RE, Johnson AG. Pancreatic metastases from breast cancer: an unusual cause of biliary obstruction. Eur J Surg Oncol. 1997;23(6):574-6.

19. Moussa A, Mitry E, Hammel P, et al. Pancreatic metastases: a multicentric study of 22 patients. Gastroenterol Clin Biol. 2004;28(10 Pt 1):872-6.

20. Nomizu T, Katagata N, Matsuoka T, et al. A Case of Breast Cancer Metastatic to the Head of the Pancreas. Breast Cancer. 1999;6(2):131-4.

21. Odzak A, Geliberti F, Farace G, et al. Tumor de páncreas: presentación infrecuente de un carcinoma de mama oculto [Pancreatic tumor: an unusual presentation of an occult breast carcinoma]. Acta Gastroenterol Latinoam. 2001;31(5):395-8.

22. Pan B, Lee Y, Rodriguez T, Lee J, Saif MW. Secondary tumors of the pancreas: a case series. Anticancer Res. 2012;32(4):1449-52.

23. Pappo I, Feigin E, Uziely B, Amir G. Biliary and pancreatic metastases of breast carcinoma: is surgical palliation indicated? J Surg Oncol. 1991;46(3):211-4.

24. Pérez Ochoa A, Sáez Hernáez F, Cajigas Fernández C, et al. Pancreatic metastases from ductal and lobular carcinomas of the breast. Clin Transl Oncol. 2007;9(9):603-5.

25. Razzetta F, Tassara E, Saro F, Sironi M, D'Ambrosio G. Rare abdominal metastases from occult lobular breast cancer: report of two cases. Updates Surg. 2011;63(2):129-33.

26. Tohnosu N, Narushima K, Sunouchi K, et al. A case of breast cancer metastatic to the tail of the pancreas. Breast Cancer. 2006;13(2):225-9.

27. Z'graggen K, Fernández-del Castillo C, Rattner DW, Sigala H, Warshaw AL. Metastases to the pancreas and their surgical extirpation. Arch Surg. 1998;133(4):413-7; discussion 418-9.

28. Masetti M, Zanini N, Martuzzi F, et al. Analysis of prognostic factors in metastatic tumors of the pancreas: a single-center experience and review of the literature. Pancreas. 2010;39(2):135-43.

\section{Sources of funding: None}

Conflict of interest: None

\section{Date of first submission: May 9, 2017}

Last received: June 13, 2017

Accepted: June 26, 2017

\section{Address for correspondence:}

Everton Cazzo

Departamento de Cirurgia da Faculdade de Ciências Médicas da Universidade Estadual de Campinas (FCM-UNICAMP)

Rua Alexander Fleming, s/no

Cidade Universitária Zeferino Vaz — Campinas (SP) — Brasil

CEP 13085-000

Tel. (+55 19) 3521-9450

E-mail: notrevezzo@yahoo.com.br 